\title{
Antiviral prospective of Tinospora cordifolia on HSV-1
}

\author{
R. Pruthvish and S.M.Gopinatha* \\ Department of Biotechnology, Acharya Institute of Technology, Bengaluru, \\ Karnataka 560107, India \\ *Corresponding author
}

A B S T R A C T

Keywords

Herpes simplex

Virus; Tinospora

Cordifolia;

Virus titration;

Virucidal assay

Article Info

Accepted:

30 December 2017

Available Online:

10 January 2018
HSV-1 also known as Oral herpes causes sores or lesions in the gums or near the mouth. Dry stem of Tinospora cordifolia is powdered and extraction is carried out in soxhlet apparatus using the solvent Methanol and Ethyl Acetate in the ratio 80:20. The crude extract was subjected to prelimnary phytochemical analysis which indicated the presence of Saponins, alkaloids, phytosterols and triterpenoids. The preparation of virus pool was carried out using Vero cell lines. MTT assay was conducted and the cytotoxicity level of T.corfiolia on the cells was obtained as $315.68 \pm 7.8$. Viral titration was carried out followed by Virucidal assay and it was concluded that T.cordifolia inhibits the growth of HSV by $61.43 \%$ at $10 \mathrm{TCID}_{50}$.

\section{Introduction}

Herpes is a Viral infection caused by Herpes simplex Virus (HSV). Herpes can be classified into two types as HSV-1 and HSV-2 based on the area of infection. At present no cure or vaccine is availiable for this particular disease. Paracetamol, lidocaine, acyclovir and valacyclovir are the commonly available antiviral medication which may help lessen the severity of the infection (1). The research work carried out aims at identification of a competent drug capable of inhibiting the growth of virus which inturn will lead to reduction of the symptoms faced during the outbreak of Herpes. Though controversies prevail research has proved that the use of food rich in Lysine, argenine and citric acid may lower the symptoms or severity of the outbreak (2). Many herbal extracts including ginger, garlic, onion, banana, honey, goldenseal, grape seed extract are known to reduce the blisters caused by herpes simplex virus yet not known to completely cure the disease (3). T.cordifolia is one among the most ancient herb used by the medical practitioners in cure of a wide variety of diseases. The plant has been used since time immemorial in curing of skin problems, allergies, inflammation and is used in 
preparation of many ayurvedic medicines(4). Researchers have proved that the plant contains a wide range of secondary metabolites like the tannins, alkaloids, cardiac glycosides, tannins, saponins, triterpenoids, phytoserols and polyphenols which have proved to be of great medicinal value and act as immunomodulators, antidiabetic medicine, anti allergic, anti leprotic and anti inflammatory agents(5). Recent research was conducted and a remarkable activity has been proved on the activity of T.cordifolia extract on HIV. Also few studies have been conducted on the antiviral properties of Tinospora and have been reported to be of great value. Therefore, the objectives of this work were (i) to test the efficacy of crude extract of T.cordifolia on HSV-1 (ii) to calculate the percentage inhibition of HSV by T.cordifolia extract.

\section{Materials and Methods}

\section{Collection of raw materials}

Fresh plant material of T.cordifolia was procured from Tellicherry a town in Kannur District of Kerala state in south India. The plant material was shade dried until all the water molecules evaporated and plants became well dried for grinding(6). Fig 1 .

\section{Preparation of plant Extract}

Dry stem of T.cordifolia was powdered and is used for extraction using soxhlet apparatus(7). The solvent used was methanol and ethyl acetate in the ratio 80:20. Crude extract is obtained and carried for phytochemical analysis.

\section{Phytochemical analysis}

Phytochemical analysis is conducted to analyze the crude extract obtained from T.cordifolia.

\section{Preparation of culture media}

Stock cells and Herpes Simplex Virus (HSV1) was cultured in MEM along with $10 \%$ inactivated $\mathrm{FBS}, 100 \mathrm{IU} / \mathrm{ml}$ of penicillin, $100 \mu \mathrm{g} / \mathrm{ml}$ of streptomycin and $5 \mu \mathrm{g} / \mathrm{ml}$ amphotericin $\mathrm{B}$ in a $\mathrm{CO}_{2}$ incubator with $5 \%$ $\mathrm{CO}_{2}$ at $37^{\circ} \mathrm{C}$ until confluency. The cells were dissociated with TPVG solution (0.2\% trypsin, $0.02 \%$ EDTA, $0.05 \%$ glucose in PBS) (8).

\section{Preparation of virus pool}

A monolayer cell culture was prepared and inoculated with $100 \mu \mathrm{l}$ of virus suspension and was incubated for 1 hour at $37^{\circ} \mathrm{C}$ for virus adsorption. After 1 hour of incubation $5 \mathrm{ml}$ of MEM along with $2 \%$ serum was added onto the monolayer and incubated at $37^{\circ} \mathrm{C}$ and observation of cytopathic effect (CPE) was practical 24 hour onwards. The cells were frozen at $-70^{\circ} \mathrm{C}$ and thawed at RT thrice repeatedly, on observation of $100 \% \mathrm{CPE}$ and the supernatant i.e. cell free extract was collected by centrifuging the cell suspension (8).

\section{MTT Assay}

The test drug was weighed and dissolved in distilled DMSO and volume was made up using MEM supplemented with $2 \%$ inactivated FBS to obtain a stock solution of 1 $\mathrm{mg} / \mathrm{ml}$ concentration and sterilized by filtration (9). Trypsinization was carried out and the cell count was adjusted to $1 \times 10^{5}$ cells/ $\mathrm{ml}$ by diluting it with MEM containing $10 \%$ FBS. $0.1 \mathrm{ml}$ (approx. 10,000 cells) of cell suspension was added to each well of the 96 well titre plate and left for 24 hours incubation (10). After the incubation the supernatant was removed and the partial monolayer was washed with fresh media. Subsequently $100 \mu \mathrm{l}$ of different concentrations of the test drug were added to the microtitre plates with partial monolayer. The microtitre plates were 
incubated in $\mathrm{CO}_{2}$ incubator at $37^{\circ} \mathrm{C}$ and $5 \%$ $\mathrm{CO}_{2}$ for 3 days. Microscopic examination of the plates was done on regular interval of $24 \mathrm{~h}$ and the observations were recorded. After 72 $\mathrm{h}$, the drug solutions were discarded from the wells and $50 \mu \mathrm{l}$ of MTT in PBS was added to each well (10). The plates were lightly shaken and incubated for $3 \mathrm{hr}$ at $37^{\circ} \mathrm{C}$ in $5 \% \mathrm{CO}_{2}$ atmosphere. The supernatant was removed and the plate was treated with $100 \mu 1$ of propanol to solubilise formazan and the absorbance at $540 \mathrm{~nm}$ was measured using microtitre plate reader (12). The percentage growth inhibition was calculated and the $\mathrm{CTC}_{50}$ value is generated from the dose-response curves for each cell line.

\section{Virus Titration}

The flask containing the monolayer was tripsinized and was seeded into a 96 well plate with an approximate 10,000 cells/well. The virus stock was serially diluted using tissue culture medium containing $2 \%$ serum. Further $100 \mu 1$ of each dilution was added into 6 wells each of a 96 well microtitre plates and it is incubated at $37{ }^{\circ} \mathrm{C}$ with $5 \% \mathrm{CO}_{2}$ atmosphere and was observed for viral CPE at every 24 hour interval. 50\% Tissue Culture Infect $\left(\mathrm{TCID}_{50}\right)$ was calculated using Reed and Muench method (13).

\section{Virucidal Assay}

The virus suspensions of $10 \mathrm{TCID}_{50}$ were incubated with test compounds of concentration $100 \mu \mathrm{g} / \mathrm{ml}$ and $50 \mu \mathrm{g} / \mathrm{ml}$. (14). The solvent which was used to dissolve test compound along with virus suspension is used as virus control. After 1 hour, $100 \mu 1$ of each mixture containing the test drug and virus suspension was added to the monolayer cultures which were grown in 96 well microtitre plates. CPE was observed every 24 hours to 96 hours and was compared with control and the readings are jotted down and are scored.

\section{Results and Discussion}

$25 \mathrm{~g}$ of dried and powdered stem of T.cordifolia was extracted using methanol and ethyl acetate in the ratio 80:20 for a total volume of $0.4 \mathrm{~L}$ in the soxhlet apparatus. The yield of extract obtained was $0.95 \mathrm{~g}$ which is equivalent to $3.8 \%$.

The crude sample obtained by extraction was subjected to phytochemical analysis using the standard tests for phytochemical analysis as stated in Table 1 and was noted for the presence of Saponins, Alkaloids, Phytosterols and Triterpenoids.

The crude sample was aliquoted into a range of concentrations as represented in Table 2 to check the percentage cytotoxicity level by means of the MTT assay. The percent cytotoxicity offered by cells under varying concentration levels is as noted in Table 2 and the $\mathrm{CTC}_{50}$ was obtained as $315 \pm 7.5 \mu \mathrm{g} / \mathrm{ml}$. Fig 1 represents the Cytotoxic effect of the test drug on the Vero Cell lines under $1000 \mu \mathrm{g} / \mathrm{ml}$, $500 \mu \mathrm{g} / \mathrm{ml}$ and control (Fig 2).

Virus titration was carried out in a 96 well plate with an approximate 10,000 cells/well. After further carrying out of the dilutions and incubation TCID 50 was calculated using Reed and Muench method (13).

Table 3 represents the microscopic observation of the growth of the organism and Table 4 represents the calculation of the accumulated value based on the Reed and Muench method.

The observation proves that the mortality rate in the dilution $10^{-5}$ is higher than $50 \%$ and in $10^{-6}$ is $13 \%$. Thus the $\mathrm{TCID}_{50}$ was calculated using the formula as stated below: 


$$
\begin{aligned}
& T_{C I} D_{50}=\frac{(\% C P E \text { at dilution next above } 50 \%)-50}{(\% \text { CPE at dilution next above } 50 \%)-(\% \text { CPE at dilution next below } 50 \%)} \\
& \frac{71-50}{771-13}=\frac{21}{58}=0.36 \text { or } 0.4
\end{aligned}
$$

Negative logarithm of the lowest dilution $=-6.0$ and proportionate distance $(0.4) * \log$ dilution factor $=-0.4$. Thus the virus titre obtained for the virus was $10^{-6.4} / \mathrm{ml}$

In the presence of test drug the virucidal assay measures less than or equal to $50 \%$ reduction in viral titre when compared to the untreated cells. The inhibition is determined using end point titration which will evaluate the virucidal activity after preincubation of the virus along with the T,cordifolia extract. 50\% end point titration is carried on confluent monolayers, infected with 10 fold serial dilutions in a 96 well titre plate. After incubation $\mathrm{CPE}$ was calculated and the percentage protection offered was calculated and is tabulated in Table 4 (Fig 3). It was observed that at a test concentration level of $100 \mu \mathrm{g} / \mathrm{ml}$ and $50 \mu \mathrm{g} / \mathrm{ml}$ the percentage protection offered is approximately $61.43 \%$ and $23.22 \%$ respectively.

\begin{tabular}{|c|c|c|}
\hline Sl. No & Test & $\begin{array}{c}\text { Tinospora cordifolia } \\
\text { Extract }\end{array}$ \\
\hline 1 & $\begin{array}{l}\text { Test for carbohydrates } \\
\text { a. Molisch's test }\end{array}$ & - \\
\hline 2 & $\begin{array}{l}\text { Test for Glycosides } \\
\text { a. Keller-Killiani test }\end{array}$ & - \\
\hline 3 & $\begin{array}{l}\text { Test for Saponins } \\
\text { a. Foam test }\end{array}$ & + \\
\hline 4 & $\begin{array}{l}\text { Test for Alkaloids } \\
\text { a. Mayer's test } \\
\text { b. Dragendrodroff's test }\end{array}$ & $\begin{array}{l}+ \\
+\end{array}$ \\
\hline 5 & $\begin{array}{l}\text { Test for Flavonoids } \\
\text { Alkaline reagent test }\end{array}$ & - \\
\hline 6 & $\begin{array}{l}\text { Test for Phenolics and Tannins } \\
\text { a. Ferric chloride test } \\
\text { b. Test for Tannins }\end{array}$ & $\begin{array}{l}- \\
-\end{array}$ \\
\hline 7 & $\begin{array}{l}\text { Test for Phytosterols and } \\
\text { Triterpenoids } \\
\text { a. Leiberman-Bucharat test } \\
\text { b. Salkowaski test }\end{array}$ & $\begin{array}{l}+ \\
+\end{array}$ \\
\hline 8 & $\begin{array}{l}\text { Test for fixed oils and fats } \\
\text { a. Oily spot test }\end{array}$ & - \\
\hline
\end{tabular}

Table.1 Preliminary Phytochemical tests for Tinospora cordifolia extract 
Table.2 Cytotoxicity testing against Vero cell lines

\begin{tabular}{|r|c|c|r|r|}
\hline Sl. No & $\begin{array}{c}\text { Name of } \\
\text { Test sample }\end{array}$ & $\begin{array}{l}\text { Test Conc. } \\
(\boldsymbol{\mu g} / \mathbf{m l})\end{array}$ & \% Cytotoxicity & $\begin{array}{c}\text { CTC } \\
(\boldsymbol{\mu g} / \mathbf{m l})\end{array}$ \\
\hline 1 & T.C (Met. \& EA) & $\mathbf{1 0 0 0}$ & $\mathbf{7 9 . 1 7} \pm 0.7$ & $\mathbf{3 1 5 . 8 6} \pm 7.5$ \\
& & 500 & $60.71 \pm 1.4$ & \\
& & 250 & $46.18 \pm 0.5$ & \\
& & 125 & $27.18 \pm 0.6$ & \\
& & 62.5 & $12.00 \pm 1.4$ & \\
\hline
\end{tabular}

Table.3 Microscopic Observation of 96 titre plate

\begin{tabular}{|l|l|l|l|l|l|l|}
\hline Dilutions & \multicolumn{7}{|c|}{ Observation } \\
\hline $10^{-1}$ & - & - & - & - & - & - \\
\hline $10^{-2}$ & - & - & - & - & - & - \\
\hline $10^{-3}$ & - & - & - & - & - & - \\
\hline $10^{-4}$ & - & - & - & - & - & - \\
\hline $10^{-5}$ & - & + & - & + & - & - \\
\hline $10^{-6}$ & + & - & + & + & + & + \\
\hline $10^{-7}$ & + & + & + & + & + & + \\
\hline Controls & + & + & + & + & + & + \\
\hline
\end{tabular}

"+” = Survived, “_“ Dead

Fig.1 Dry stem of T.cordifolia

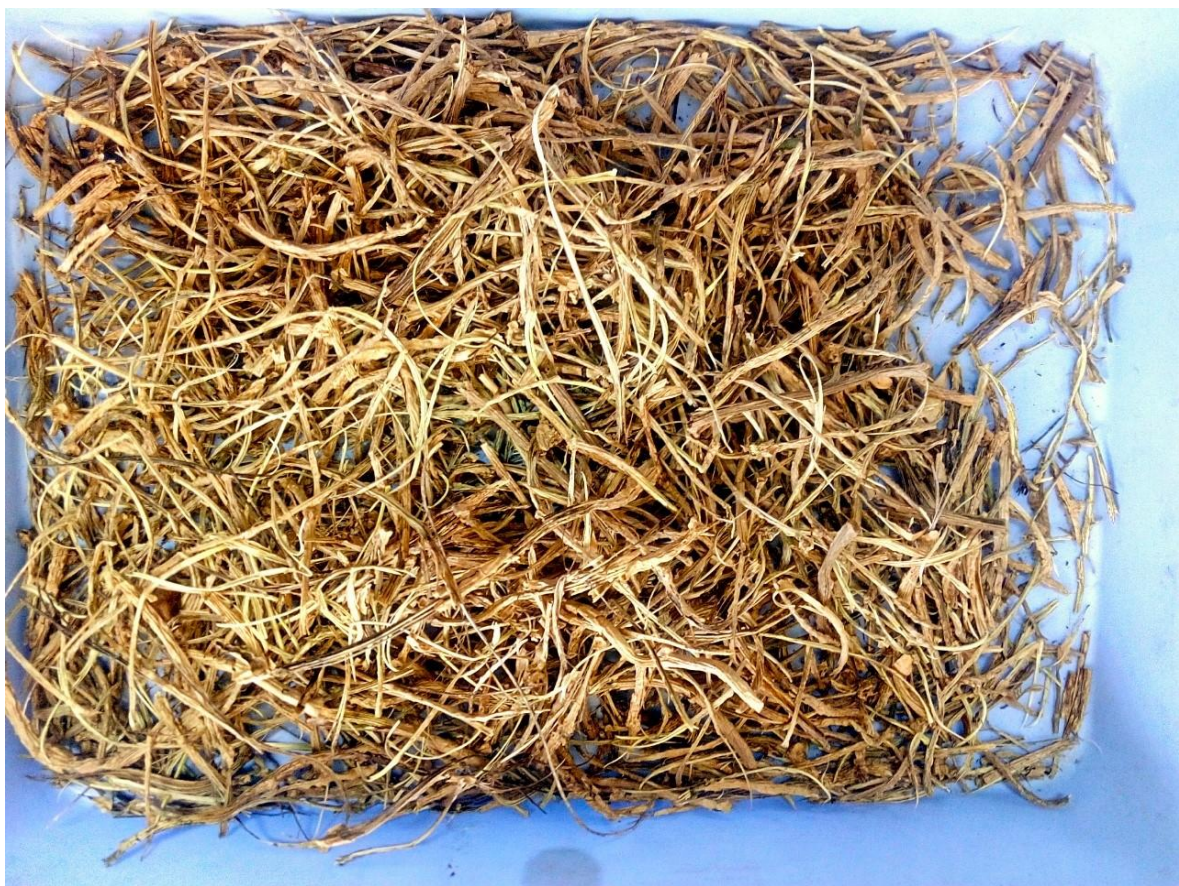


Fig.2 Cytotoxic effect of the sample on Vero cell lines

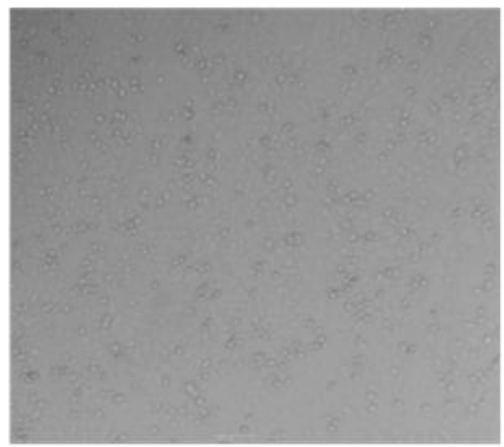

Control (Vero)

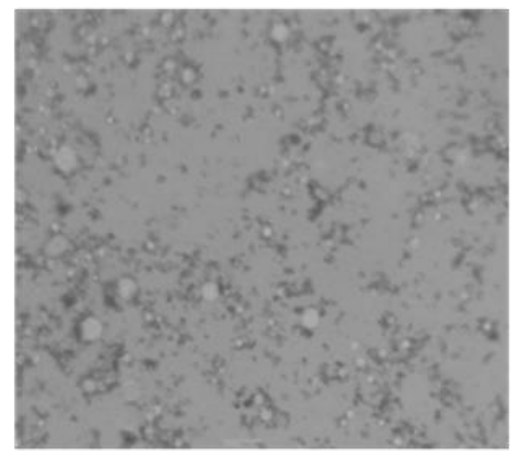

Vero T.C(Met \& EA) $(1000 \mu \mathrm{g} / \mathrm{ml})$

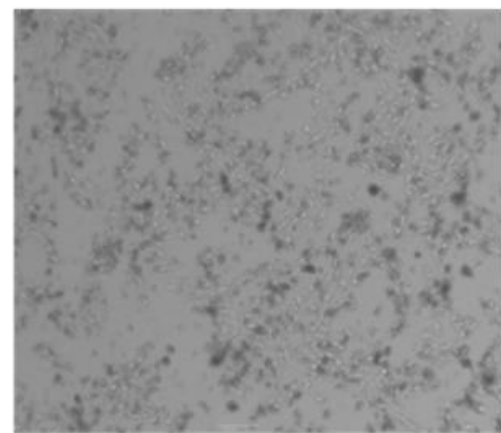

Vero T.C(Met \& EA) $(500 \mu \mathrm{g} / \mathrm{ml})$

Table 4 Arrangement of data used in computation of TCID $_{50}$ titer by Reed and Muench formula

\begin{tabular}{|c|c|c|c|c|c|c|c|}
\hline \multirow{2}{*}{$\begin{array}{c}\text { Virus } \\
\text { dilution }\end{array}$} & \multirow{2}{*}{$\begin{array}{l}\mathrm{CPE} \\
\text { ratio }\end{array}$} & \multirow{2}{*}{$\begin{array}{c}\text { Wells } \\
(+)\end{array}$} & \multirow{2}{*}{$\begin{array}{c}\text { Wells } \\
(-)\end{array}$} & \multicolumn{4}{|c|}{ Accumulated values } \\
\hline & & & & CPE & CPE & CPE & Percentage \\
\hline $10^{-1}$ & $6 / 6$ & 6 & 0 & 29 & 0 & $29 / 29$ & 100 \\
\hline $10^{-2}$ & $6 / 6$ & 6 & 0 & 22 & 0 & $22 / 22$ & 100 \\
\hline $10^{-3}$ & $6 / 6$ & 6 & 0 & 17 & 0 & $17 / 17$ & 100 \\
\hline $10^{-4}$ & $6 / 6$ & 6 & 0 & 11 & 0 & $11 / 11$ & 100 \\
\hline $10^{-5}$ & $4 / 6$ & 4 & 2 & 5 & 2 & $5 / 7$ & 71 \\
\hline $10^{-6}$ & $1 / 6$ & 1 & 5 & 1 & 7 & $1 / 8$ & 13 \\
\hline $10^{-7}$ & $0 / 6$ & 0 & 6 & 0 & 13 & $0 / 13$ & 0 \\
\hline
\end{tabular}


Table.5 Inhibitory activity of test substances against HSV-I induced cytopathic effect

\begin{tabular}{|c|c|c|c|c|}
\hline $\begin{array}{c}\text { Sl. } \\
\text { No }\end{array}$ & Sample Name & $\begin{array}{c}\mathbf{C T C}_{\mathbf{5 0}} \\
(\boldsymbol{\mu g} / \mathbf{m l})\end{array}$ & $\begin{array}{c}\text { Test Concentration } \\
(\boldsymbol{\mu g} / \mathbf{m l})\end{array}$ & $\begin{array}{c}\text { \% Protection offered } \\
\text { 10TCID }_{\mathbf{5 0}}\end{array}$ \\
\hline $\mathbf{1}$ & T.C. (Methanolic \& & $315.86 \pm 7.5$ & 100 & $62.04 \pm 3.51$ \\
& Ethyl acetate) & & 50 & $24.03 \pm 2.39$ \\
\hline
\end{tabular}

Fig.3 Inhibitory activity of test substances against HSV-1 induced cytopathic effect

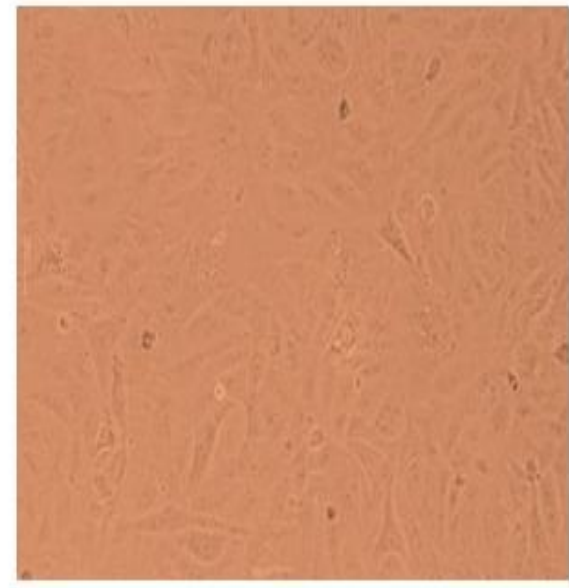

Control

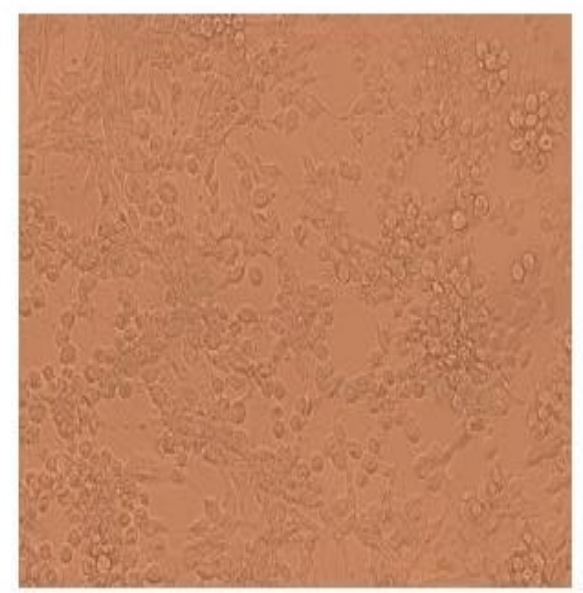

Virus Control

The Preliminary photochemical analysis confirmed the presence of saponins, alkaloids, phytosterols and triterpinoids in the crude extract obtained from T.cordifolia using methanol and ethyl acetate. Cytotoxicity

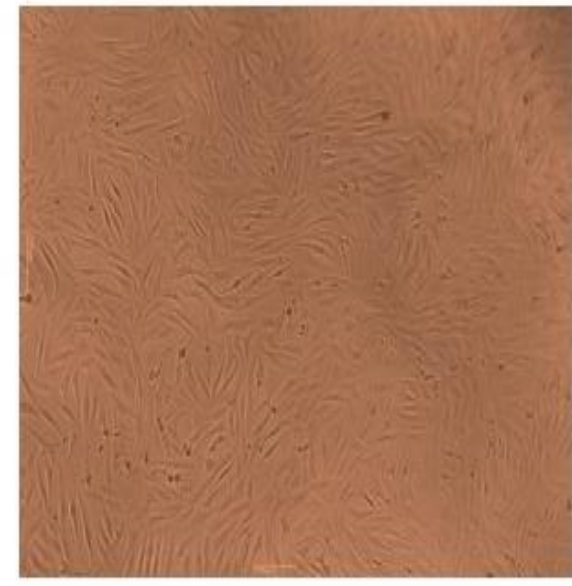

T.C. (M \& E) 100

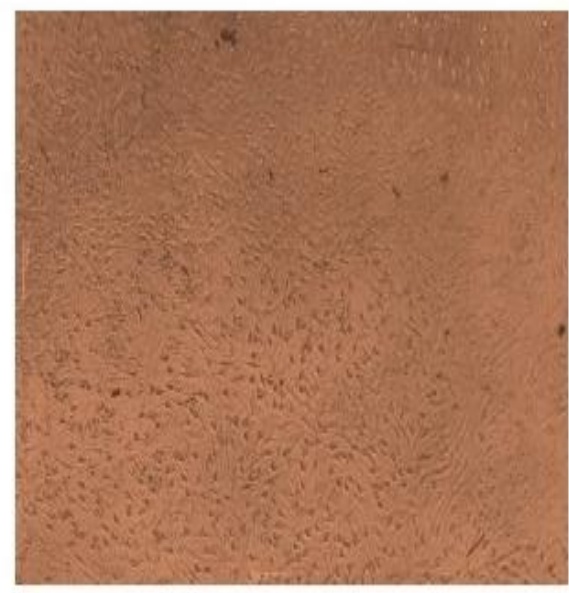

\section{T.C. (M \& E) 50}

analysis as shown in Table 5 was carried out using different test concentrations ranging from $1000 \mu \mathrm{g} / \mathrm{ml}$ to $62.5 \mu \mathrm{g} / \mathrm{ml}$ and the $\mathrm{CTC}_{50}$ was calculated to be $315.86 \pm 7.5 \mu \mathrm{g} / \mathrm{ml}$. Virus titration was carried out by Reed and Muench 
method and the value obtained was $10^{-6.4} / 1$ ml. Virucidal assay was conducted at $1_{10 T C I D}$ for the test concentration $100 \mu \mathrm{g} / \mathrm{ml}$ and $50 \mu \mathrm{g} / \mathrm{ml}$ and it can be concluded that the percentage protection offered was observed to be $62.04 \pm 3.51$ and $24.03 \pm 2.39$ respectively.

\section{References}

1. Anthony Simmons. Clinical Mani-festations and Treatment Considerations of Herpes Simplex Virus Infection. J Infct Dis. 2002; 186(1): S71-77. doi: 10.1086/342967.

2. Jo Hartley. National Cold sore remedies. Tuesday, Jan 27, 2009. http://www.naturalnews.com/025425_virus_h erpes_natural.html.

3. Petrovska B. B., Historical review of medicinal plants usage. Pharmacogn Rev., Vol 6(11) Jan 2012; 1-5.

4. Soham Saha and Shyamashree Ghosh, Tinospora cordifolia: one plant many roles. Anc Sci Life., 31(4), Apr-June 2012, pp: 151159.

5. Saganuwan Alhaji., A modified arithmetical method of Reed and Muench for determination of a relatively ideal median lethal dose (LD 50). African journal of pharmacy and pharmacology 5(12), September 2011.

6. Sasidaran, $\mathrm{S}$ et al. Extraction, Isolation and Characterization of Bioactive Compounds from Plants' Extracts, Afr J Tradit Complement Altern Med. 8(1) 2011, pp: 110.

7. Rachana Mishra and Gurucharan Kaur. Aqueous ethanolic etract of Tinospora cordifolia as a potential candidate for differentiation based therapy of Glioblastomas. Plos One, Oct 2013.

8. Francis D and Rita L. Rapid Colorometric assay for cell growth and survival modifications to the tetrazolium dye procedure giving improved sensitivity and reliability. Journal of Immunological Methods, 1986. pp: 271-277.

9. Piwen Wang, Susanne M, Henning and David Heber. Limitations of MTT and MTS- Based assay for measurement of antiproliferative activity of green tea polyphenols. PLoS ONE 5(4): e10202. doi:10.1371/journal.pone.0010202.

10. Florian M Freimoser, Claude A Jakob, Markus Aebi and Urs Tuor. The MTT (3-(4,5Dimethylthiazol-2-yl)-2,5-Diphenyl-

tetrazolium Bromide) Assay is a fast and reliable method for colorimetric determination of fungal cell densities. Appl. Environ. Microbiol.August 1999 vol. 65 no. 837273729.

11. Berridge MV, Tan AS. Characterisation of the cellular reduction of 3-(4,5dimethylthiazol-2yl)-2,5-diphenyltetrazolium bromide (MTT): Subcellular localization, substrate dependence, and involvement of mitochondrial electron transport in MTT reduction. Archives Biochem Biophys. 1993, 303:474-482.

12. Bernas T, Dobrucki J (April 2002). Mitochondrial and non-mitochondrial reduction of MTT: interaction of MTT with TMRE, JC-1, and NAO mitochondrial fluorescent probes. Cytometry 47 (4): 236242.

doi:10.1002/cyto.10080.

13. Saganuwan Alhaji., A modified arithmetical method of Reed and Muench for determination of a relatively ideal median lethal dose (LD 50). African journal of pharmacy and pharmacology September 2011. $5(12)$.

14. Measurement of virus by end point dilution assay, Virology blog, http://www.virology.ws/2009/07/13/measure ment-of-viruses-by-end-point-dilution-assay/ July 2009.

\section{How to cite this article:}

Pruthvish, R., and Gopinatha, S.M. 2018. Antiviral prospective of Tinospora cordifolia on HSV-1. Int.J.Curr.Microbiol.App.Sci. 7(01): 3617-3624. doi: https://doi.org/10.20546/ijcmas.2018.701.425 